\title{
Graduate Formation in Intellectual Property in Brazil: A Study Based on Academic Production of Thesis and Dissertations
}

\author{
Heitor de Paula Filho ', Cristina Gomes de Souza ${ }^{2}$
}

\begin{abstract}
The aim of this paper is to present information on the graduate formation in Intellectual Property in Brazil based on academic production of thesis and dissertations. This study analyzed data from 278 documents indexed in Bank of Thesis of Capes. The results show that: I) only in the last years started the formation of professionals at the master's and doctorate degree levels being necessary efforts for learning and training in the area; 2) the formation of competences is much concentrated in the Southeast and South regions of the country and in the area of Law being necessary to correct these asymmetries; and 3) the principal focus of this academic production is related to intellectual property policy followed by patents.
\end{abstract}

Keywords: intellectual property; industrial property; academic production; graduate formation.

\footnotetext{
${ }^{1}$ INPI - Instituto Nacional de Propriedade Industrial. Rua Mayrink Veiga, n 9 - Centro - Rio de Janeiro/RJ - Cep: 20090-910. E-mail: heitor@inpi.gov.br

${ }^{2}$ CEFET/RJ - Programa de Pós-Graduação em Tecnologia. Bloco E - 50. Andar - Av. Maracanã, $n^{\circ} 229$ - Maracanã - Rio de Janeiro/RJ - Cep: 2027I-I I0. E-mail: crisgsouza@gmail.com
} 


\section{Introduction}

Changes in economic environment such as globalization, growth of competition, transformation of the role of the state, rise of new industries based on technology and knowledge-intensive, preponderance of the networks of relationships and the need for sustainable development have transferred the emphasis from physical assets (tangible) to intangible assets. This context has increased the importance of Intellectual Property (IP) as mechanism to guarantee the rights and encouragement of investment (Buainain and Carvalho, 2000).

The World Trade Organization (WTO) is the main forum of international negotiations involving the intellectual property subject. In WTO are discussed questions concerning the various types of protection covered by IP rights affecting political, economic and social aspects of various countries. As there are several international agreements related to IP rights, the participation of the countries in these discussions is strategic to preserve and defend the national interests.

Therefore, it's essential the formation of competences in this theme - people who know to use the regulatory aspects and the mechanisms and procedures relating to the IP system to promote the technological development of the country. The capacity building can occur through various actions - training, courses, work experience, researches in graduate programs and others.

The aim of this paper is to present information on the graduate formation in IP in Brazil. The article tries to answer the following questions: Is there graduate formation in IP in the country? Where is the capacity building in IP located? What is the issue of this academic production and in which knowledge areas is concentrated? The research was based on data from 278 abstracts of dissertations and thesis retrieved of the Bank of Thesis of Capes.

\section{Context}

Intellectual Property is an expression that means a set of rights that refers to creations of the human mind as inventions, literary and artistic works, and symbols, names, images, and designs used in commerce (WIPO, 2009). IP includes industrial property, copyright and related rights, software register and sui generis protection (topography of integrated circuits, cultivars protection and traditional knowledge). Industrial property includes patents, trademarks, industrial designs and geographic indications of source or appellations of origin. The Brazilian Industrial Property Law (Law No 9.279/96) also covers technology transfer and repression of unfair competition.

The Union Convention of Paris - UCP was the first international treaty of industrial property. UCP was signed in 1883 by 14 countries including Brazil (INPI, 2009). After CUP, various others treaties and agreements were firmed as Berne Convention for the Protection of Literary and Artistic Works (1886), Madrid Agreement Concerning the International Registration of Marks (189I), Hague Agreement Concerning the International Registration of Industrial Designs (1934), Nice Agreement Concerning the International Classification of Goods and Services for the Purposes of the Registration of Marks (1957), Strasburg Agreement for the international classification of patents (197I), Patent Cooperation Treaty - PCT (1978) and others.

In the last decades of the twentieth century, because of the changes in the international scene caused by the economy globalization process, the increasing the importance of technology as competitive factor and the advent of the called Knowledge Society, the theme of IP rights returned to the center of discussions. Despite the resistance from developing countries, especially Brazil and India, in 1994 was signed the Agreement on Traderelated Aspects of Intellectual Property Rights - TRIPS, strengthening mechanisms of patent protection and requiring that all signatory countries recognize the patents in all technological fields, regardless of their stages of development and social and economic contexts (Gontijo, 2005).

According to Barbosa (2003 apud Chaves et al., 2007), the TRIPS Agreement has brought two important changes: the establishment of rigid rules on IP rights and loss of autonomy of each member country to adopt legislation to encourage their development. Another change was that World Trade Organization (old GATT) now has mechanisms to penalize countries that do not comply with the rules set out in agreements. 
Buainain et al. (w.d.) say that the IP is still subject of controversies and disputes in various international forums because affects interests of different actors and countries. The authors cite questions yet unresolved: "What are the objects of protection? What is the minimum and maximum protection? How to harmonize the interests of innovative companies, the rights of IP holders and the interests of the society? How to balance the position of developed countries on IP - in favor of a strong system of protection - and the need to promote the development of poorer countries?"

Despite the controversy, Brandelli and Jaguaribe (2007) mention that all the countries with high technological performance make use of patent system. These countries invest significant amounts in the operation of their systems (USPTO - United States Patent and Trademark Office, for example, has an annual budget of about \$ 1.6 billion). The authors also emphasize that IP systems are used with the following objectives: to give value to intangible assets; facilitate the financing of innovation and to make more attractive economically investments in R\&D; enhance the attention and respect to demands of consumers; and promote technical and commercial cooperation in favour to innovation.

Nowadays Brazil is responsible for about $2 \%$ of global production of knowledge occupying the fifteenth position in the ranking of international publications indexed on the base of ISI/Web of Science. However, the same is not true in the case of patents indicator. In order to encourage technological development, the Brazilian government is promoting various actions such as the promulgation of the Innovation Law (Law No. 10.973/04) and the Law of Well (Law II.196/06), the creation of Sectorial Funds to finance projects of innovation, the supporting the creation of centers of technological innovation (agencies or nucleus) in the Science and Technology Institutions (STIs) to facilitate the university technology transfer and others.

This new scenario has increased the demand for professionals with IP knowledge. To attend this necessity various trainings, courses, workshops and events have been offered to spread the culture of IP in the country. With the aim of training people with higher level of qualification, it was created - in 2007 - the Innovations and Intelletual Property Master's Program offered by the
National Institute of Industrial Property (INPI) which is the Brazilian Office of Industrial Property. But, nowadays, what is the reality of expertise in IP in Brazil considering the formation of professionals at the master's and doctorate degree levels?

\section{Method}

Capes - Coordination for the Improvement of Higher Education Personnel is a Foundation within the Ministry of Education in Brazil whose activities are organized in four actions: assessment of graduate programs; access and dissemination of scientific production; investment in formation of high level researchers; and promoting of international scientific cooperation. Capes provides free access to abstracts of all theses and dissertations accepted by Brazilian universities since 1987. The large body of information in this database allows you to identify competences and research trends in various areas of knowledge.

The research to identify expertise in Intellectual Property in Brazil was based on abstracts of theses and dissertations indexed in this database. The information retrieval can be done by theme, author, institution and year. In this study, it was used the terms 'intellectual property' and 'industrial property' as parameter of search covering all documents since 1987.

The following data from the abstracts of thesis and dissertations were analyzed: level of academic degree; year (to show the evolution of academic production); region and Unit of the Federation; institution; area of academic knowledge; and content of the document based on reading of the abstracts. The contents of the documents were classified in: cultivars protection; topography of integrated circuits; traditional knowledge; software register; copyright and related rights; trademarks; patents; industrial design; geographic indications of source or appellations of origin; technological prospective; technology transfer; and industrial property policy.

\section{Results}

The search resulted in 233 abstracts retrieved with the term 'intellectual property' and 103 with the term 'industrial property'. Thirty-five (35) documents were retrieved with the two terms of search and were re- 
moved to avoid repeated duplication of information. Of the remaining 278 abstracts, 23 were discarded because they didn't specifically mention the subject studied. Then the universe of study was reduced to 278 abstracts $221(79,5 \%)$ abstracts of dissertations and 57 (20,5\%) abstracts of thesis as showed in Figure I.

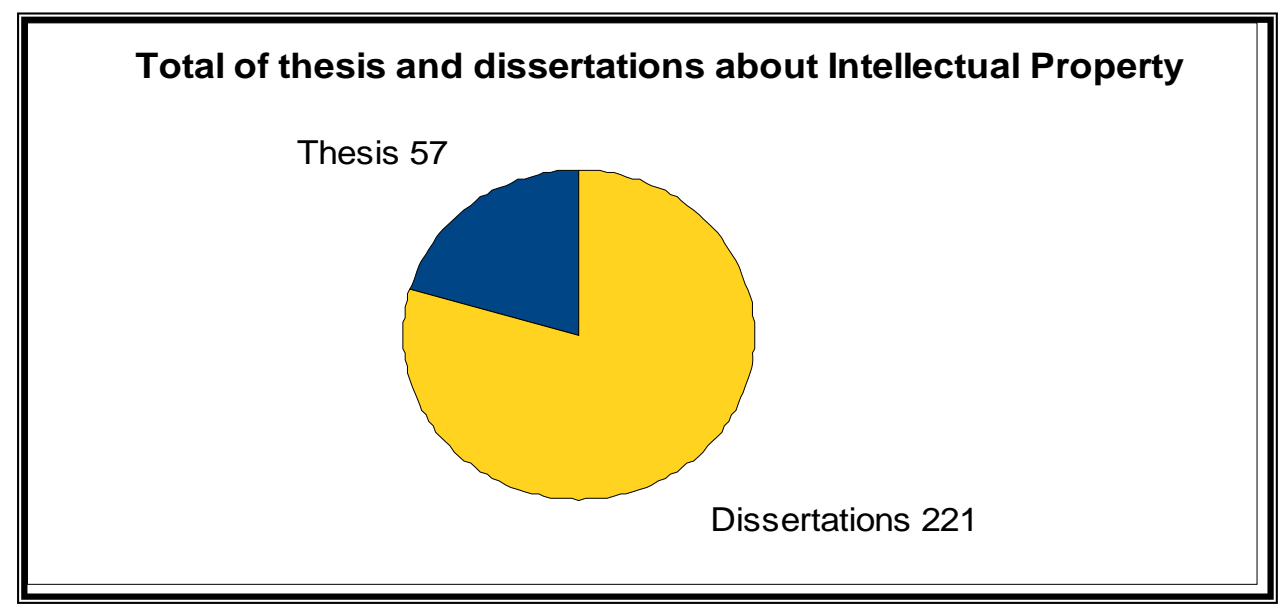

Figure I. Total of thesis and dissertations.

Another aspect observed in the study was the distribution of the academic production of thesis and dissertations over the years with the objective of to identify if is happening an increased of interest by the theme. Figure 2 illustrates this evolution.

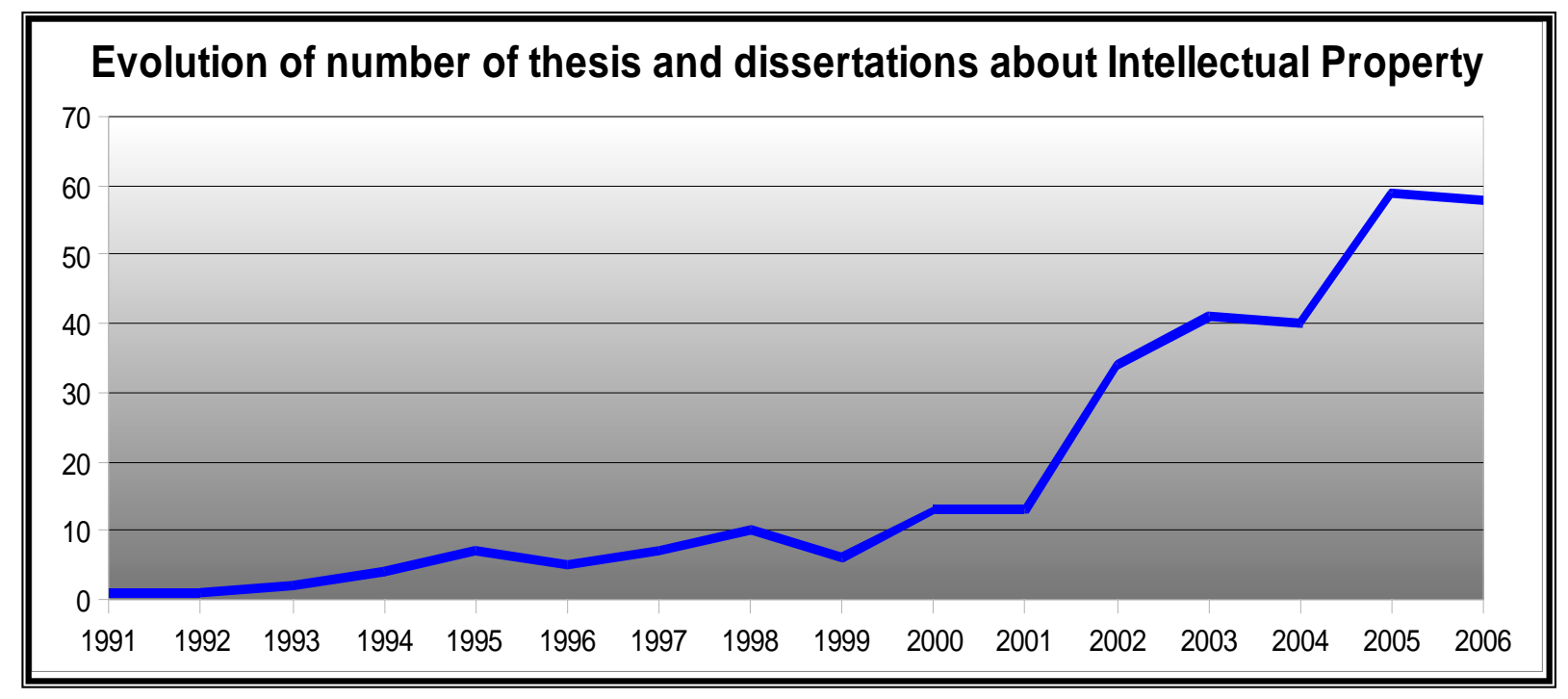

Figure 2. Evolution of number of thesis and dissertations about Intellectual Property.

Although the database accessed covers all the thesis and dissertations of Brazilian universities since 1987, it was observed that the first academic production about IP considering the parameters of search adopted - was in
1991. The growth of the number of thesis and dissertations was small in the period 1991-200I. Only in 2002 begins a significant increase of this academic production. It's possible to say that, in the last ten years, the growth 
of the number of thesis and dissertations about IP was greater in percentage than the total of Brazilian dissertations and thesis considering all knowledge areas. In 1997, for example, there were only 7 dissertations and thesis about IP in the universe of 15.542 . In 2008, this number increased to 58 in the universe of 41.645 as illustrated in Table I.

\begin{tabular}{|c|c|c|}
\hline Year & $\begin{array}{c}\text { Thesis and dissertations about Intel- } \\
\text { lectual Property }\end{array}$ & $\begin{array}{c}\text { Total of thesis and dissertations in } \\
\text { Brazil (data from Capes) }\end{array}$ \\
\hline 1997 & 7 & 15.542 \\
\hline 1998 & 10 & 16.630 \\
\hline 1999 & 6 & 20.233 \\
\hline 2000 & 13 & 23.708 \\
\hline 2001 & 13 & 26.072 \\
\hline 2002 & 34 & 31.326 \\
\hline 2003 & 41 & 35.742 \\
\hline 2004 & 40 & 34.945 \\
\hline 2005 & 59 & 39.691 \\
\hline 2006 & 58 & 41645 \\
\hline
\end{tabular}

Table I - Evolution of number of thesis and dissertations in the last ten years

Considering the five Brazilian regions, it's possible to observe that SE - Southeast region concentrates the greatest quantity of thesis and dissertations about IP of the country, representing $60 \%$ of the total. In sequence appear the regions $\mathrm{S}$ - South (21\%), CW - Central-
West (10\%), NE - Northeast (6\%) and N - North (3\%) as showed in Figure 3a. This result follows the distribution of GDP in which the Southeastern region represents $57 \%$ of total. The participation of the five Brazilians regions in GDP is illustrated in Figure $3 \mathrm{~b}$.

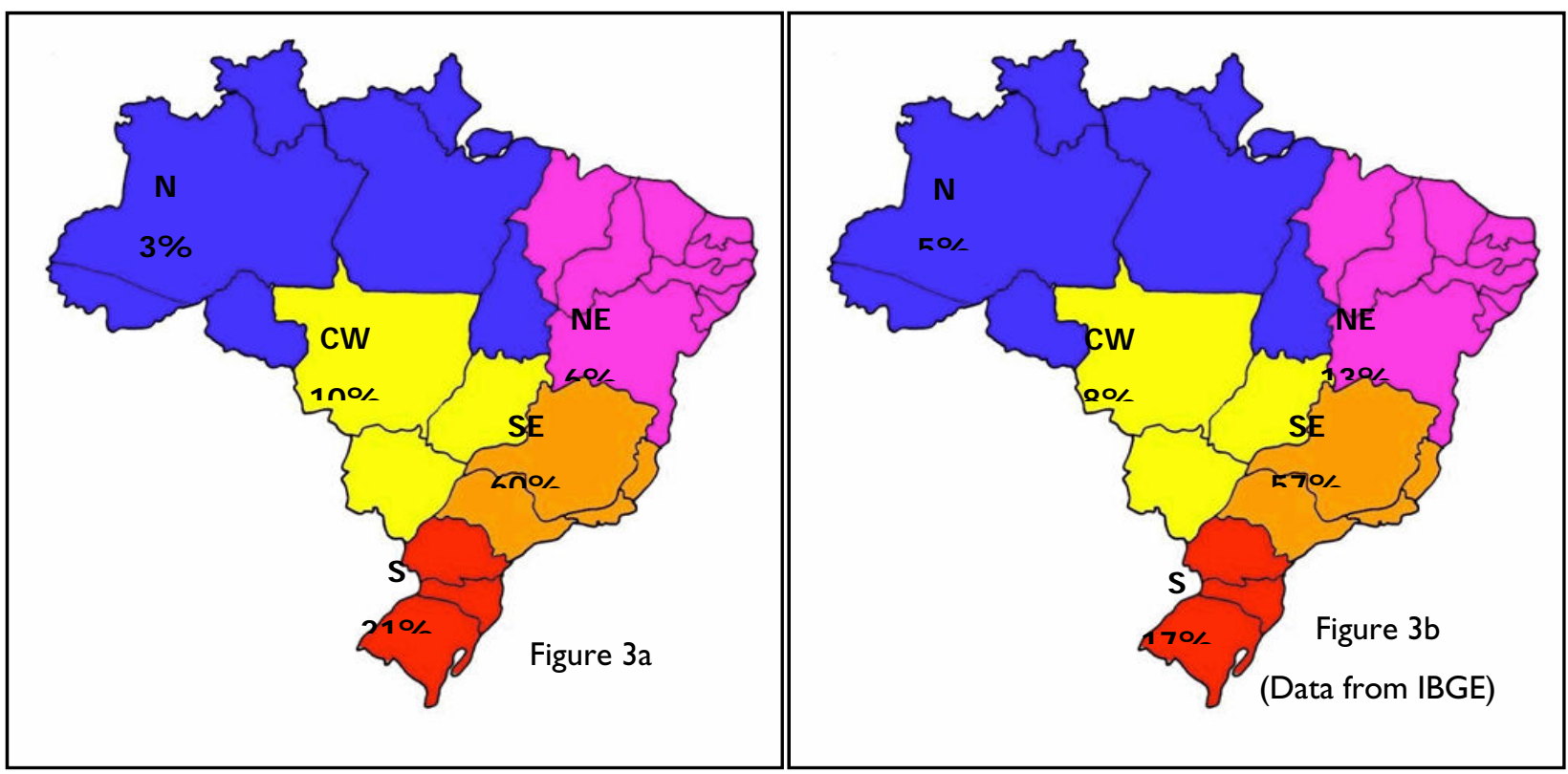

Figure 3. (a) Distribution of thesis and dissertation about IP; (b) GDP by Brazilian regions. 
The results by Units of Federation showed that the universities of state of São Paulo - SP concentrate 88 thesis and dissertations about IP representing approximately $32 \%$ of national production. In the sequence are the following Units of Federation: Rio de Janeiro - RJ (58); Minas Gerais - MG (25); Distrito Federal - DF
(24); Rio Grande do Sul - RS (22); Paraná - PR (19); Santa Catarina - SC (15); Pernambuco - PE (6); Amazonas - AM (5); Bahia - BA (4); Paraíba - PB (3); Pará - PA (3); Ceará - CE (2); Goiás - GO (2); Espírito Santo - ES (I); and Mato Grosso do Sul - MS (I) as ilustrated in Figure 4.

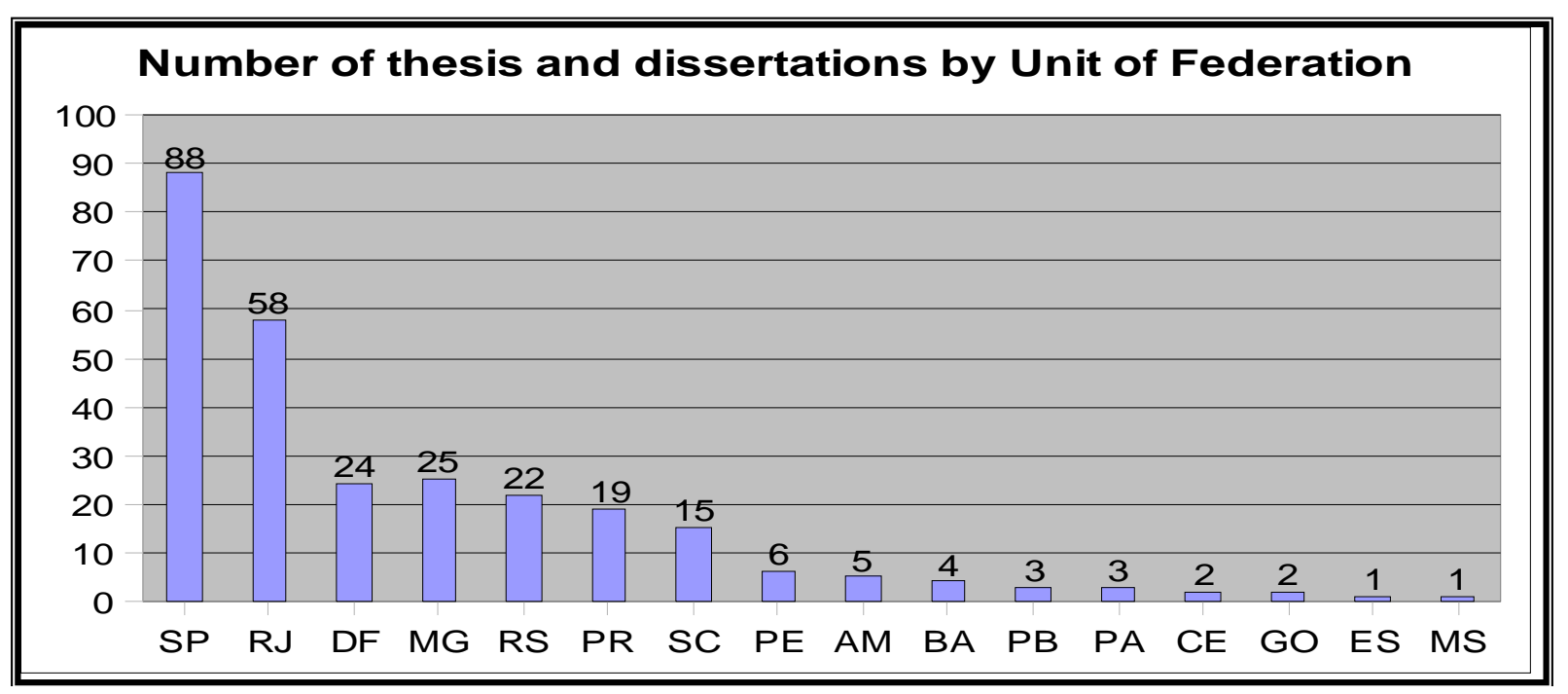

Figure 4. Academic production of thesis and dissertation by Units of Federation.

This academic production analyzed was development in graduate programs of 65 institutions. The ranking of the II universities with the largest number of thesis and dissertations about IP is formed by USP (22); UFRJ (2I);
PUC-SP (2I); UNB (2I); UNICAMP (I5); UFSC (II); UFMG (9); UFPR (9); UNIMEP (8); UFRGS (7); and CEFET/RJ (7). Figure 5 presents the ranking of the universities that represent $53 \%$ of national production.

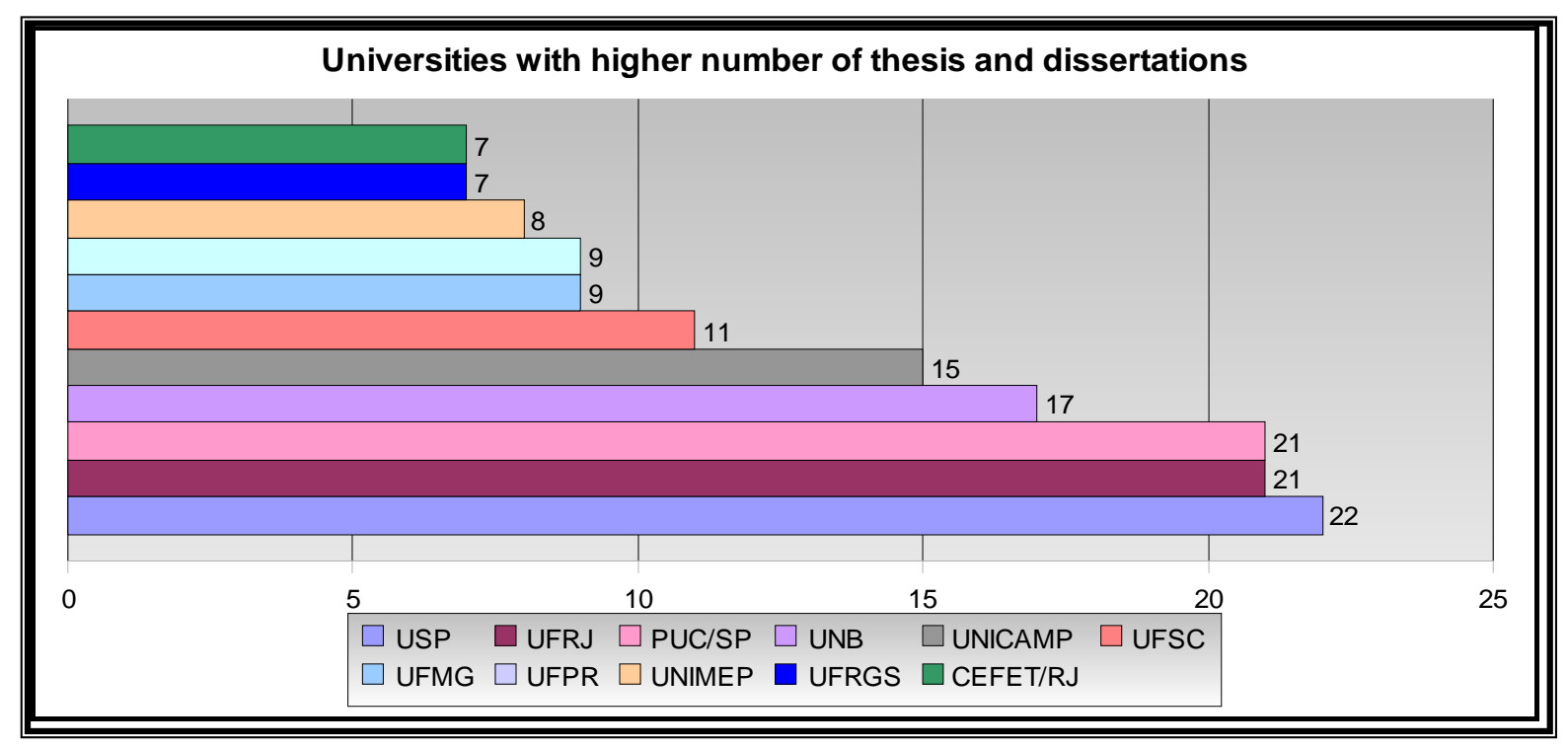

Figure 5. Ranking of the universities with the higher number of thesis and dissertation. 
It was also identified the knowledge areas that concentrate expertise in IP subject. For this analyze was considered the classification adopted by Capes which is used by graduate programs in Brazil. The classification of
Capes divides the knowledge areas in Great Areas that are subdivided into subareas. Table 2 illustrates the distribution of the thesis and dissertation by Great Area of knowledge as informed by the graduate programs.

\begin{tabular}{|l|l|}
\hline Great Areas of Knowledge & Total \\
\hline Applied Social Sciences & 154 \\
\hline Human Sciences & 32 \\
\hline Engineering & 26 \\
\hline Multidisciplinary & 20 \\
\hline Exact and Earth Sciences & 17 \\
\hline Health Sciences & 13 \\
\hline Agricultural Sciences & 9 \\
\hline Biological Sciences & 5 \\
\hline Linguistics, Literature and Arts & 2 \\
\hline
\end{tabular}

Table 2 - Distribution of thesis and dissertations by Great Areas of Knowledge

Table 2 shows that Applied Social Sciences area concentrates 154 documents that represent $55 \%$ of the production. In sequence are the following areas: Human Sciences (I I,5\%); Engineering (9,3\%); Multidisciplinary (7,2\%); Exact and Earth Sciences (6\%); Health Sciences (5\%); Agricultural Sciences (3\%); Biological Sciences $(\mathrm{I}, 7 \%)$; and Linguistics, Literature and Arts (0,7\%). The concentration of thesis and dissertations in the Applied Social Sciences area can be explained by the presence of subarea of law that corresponds to II 2 documents.

Based on the reading of the abstracts was made the classification of content of the $\mathbf{2 7 8}$ thesis and dissertations. The contents considered were those related in the section method of this paper adding the item others. Therefore were considered the following items: cultivars protection (C); topography of integrated circuits (IC); traditional knowledge (TK); software register (S); copyright and related rights (CO); trademarks $(\mathrm{T})$; patents (P); industrial design (ID); geographic indications of source or appellations of origin (Gl); technological prospective (TP); technology transfer (TT); industrial property policy (IPP); and others $(\mathrm{O})$. It's important to mention that content of the thesis and dissertations could be classified in more than one item. Figure 6 illustrates the results of the classification of the abstracts by kind of content.

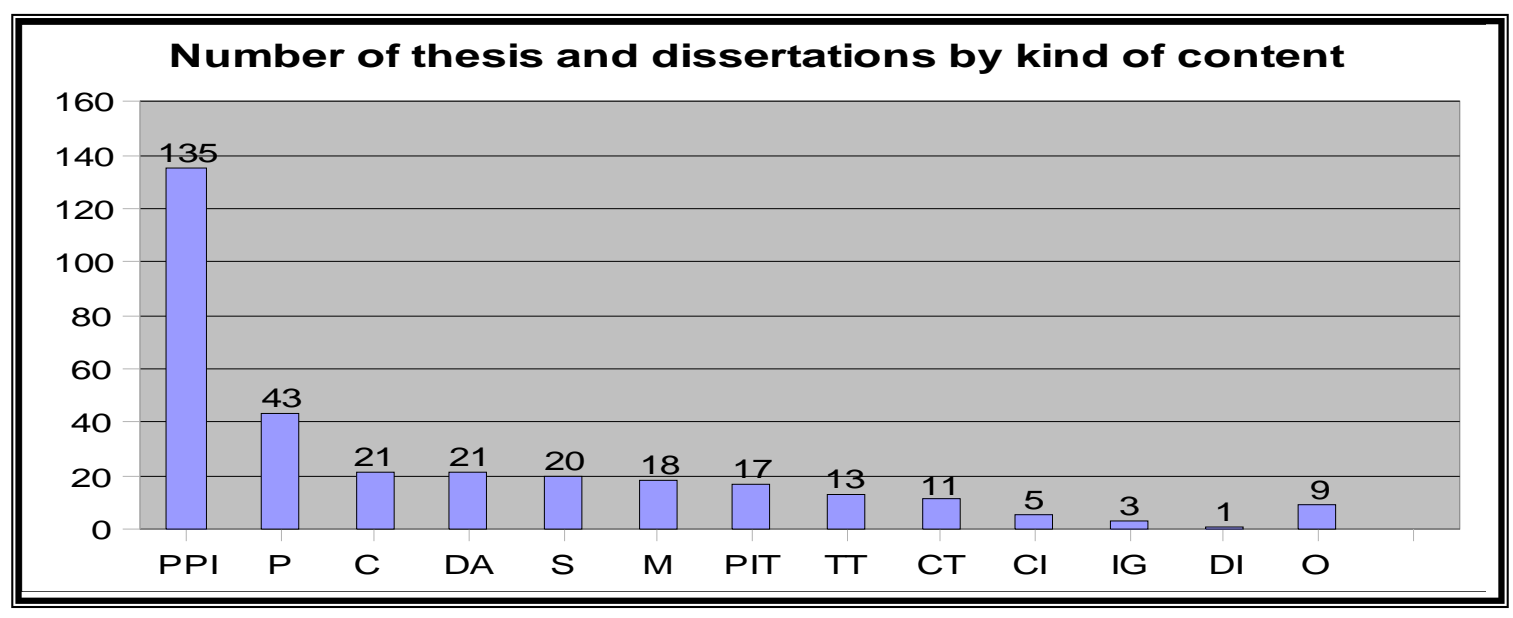

Figure 6. Academic production of thesis and dissertations by kind of content. 
The results show that the 135 abstracts were classified as content related to (IPP) representing approximately $49 \%$ of the production followed by $(\mathrm{P})$ with 43 abstracts, (C) and (CO) with $2 \mathrm{I}$, (S) with 20, (T) with 18, (TP) with 17, (TT) with 13, (TK) with II, (IC) with 5, (GI) with 3, (ID) with I and (O) with 9. Based on the results was created a chart (Figure 7) showing the relationship between knowledge area and kind of content.

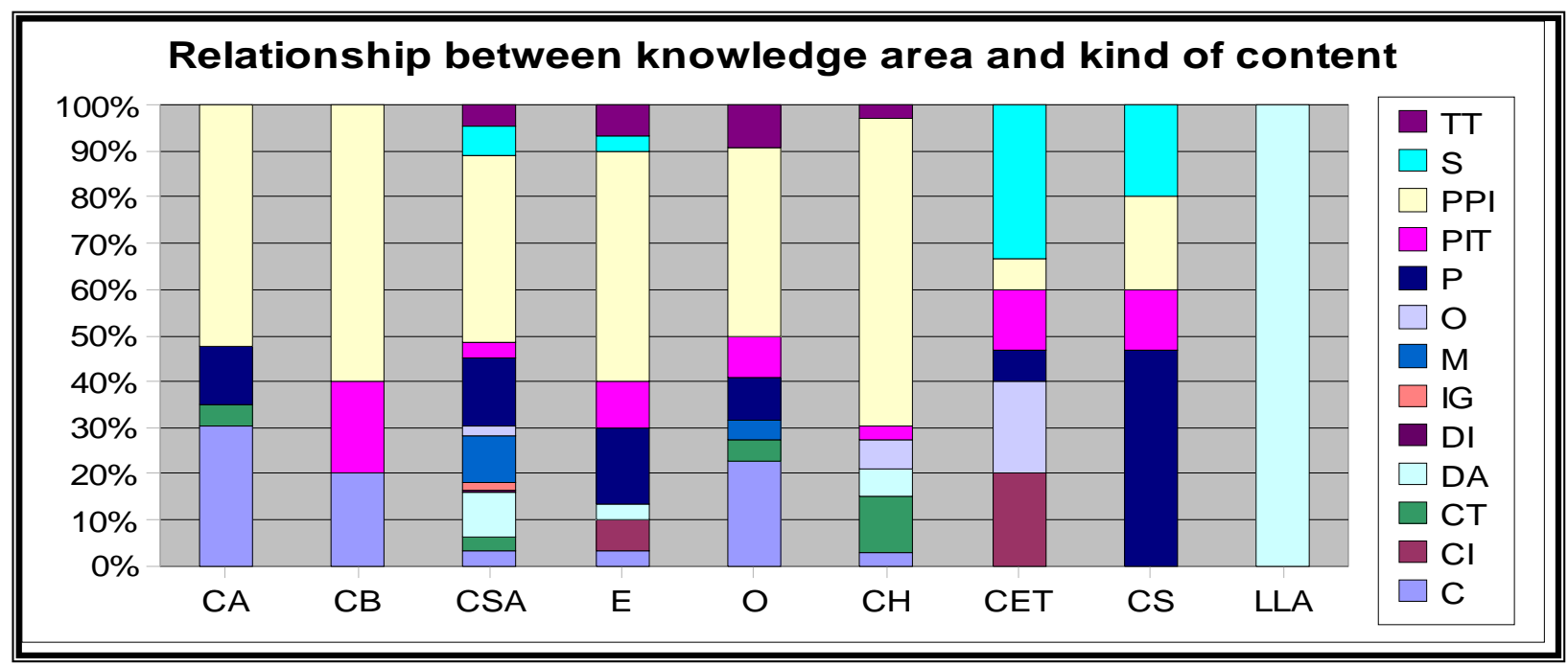

Figure 7. Relationship between knowledge area and kind of content.

\section{Discussion}

The results of the research showed that the Brazilian capacity building in IP - considering the formation of professionals at the master's and doctorate degree levels - is a fairly recent process. The first record of a dissertation in 1991 illustrates how the matter was not studied by the Academy until few years ago despite the country to have been one of the 14 members that signed the UCP in 1883 and to participate of various international agreements related to Intellectual Property.

It seems that only with the implementation of TRIPs and the new Industrial Property Law in 1996 occurred the diffusion of this subject in the academic environment. Certainly these facts combined with a series of actions and regulations related to IP contributed to the spread of this issue reflecting in the expressive increase in the production of thesis and dissertations in the last years.

The trend for the next years is to continue increasing the academic production of thesis and dissertations about IP. It's an important aspect to reduce the shortage of expertise in the country and to attend the demand of diverse institutions that integrate the Brazilian National Innovation System. Efforts have been made in this direction such as the creation of the Academy of INPI that, since 2007, offers the Innovation and Intellectual Property Master's Program.

Another challenge is that the formation of graduate students is not well distributed into the country. This asymmetry was expected and happens in all areas of knowledge. It can be explained, among other factors, by the concentration of universities, research centers and graduate programs in the Southeast and South regions of Brazil. These are the regions more developed of the country presenting the greatest participation in the Brazilian Gross Domestic Product (GDP).

The position of scientific and technological leadership of the state of São Paulo is not also surprising. This Unit of Federation, which represents $33,86 \%$ of GDP, presents the largest investment in S\&T (Science \& Technology) of the country and concentrates the highest indices of publications in international journals indexed in ISI/Web of Science database which is used to measure the indicator of scientific production of the world. 
The participation of the state of Rio de Janeiro in the production of thesis and dissertations related to IP is also significant accounting for $21 \%$ of the total. The fact of the seat of INPI (National Institute of Industrial Property) to be located in this Unit of Federation and the presence of important institutions like FIOCRUZ (Oswaldo Cruz Foundation), CENPES (Center of Research of Petrobras), UFRJ (Federal University of Rio de Janeiro) and others STIs contribute to the interest of the thematic in this state. The creation of the Academy of INPI with the goal of the formation of 25 new graduate students by year will increase considerably the participation of the state of Rio de Janeiro in this indicator in coming years.

The research showed that $55 \%$ of academic production is concentrated in Great Area of Applied Social Sciences. This concentration is result of the subarea law that represents $40 \%$ of all thesis and dissertations about IP in the country. This is another aspect that demands attention being necessary better distribution of formation of competences in others knowledge areas. Although the issue of IP has intensive relationship with legal aspects, the diffusion of this thematic in areas related to technology and management is fundamental to promote the technological development of the country.

The concentration of thesis and dissertations related to intellectual property policy (IPP) followed by patents (P) reflects the interest of research development about the public policy and the regulations to incentive the innovation adopted by the Brazilian government. In this aspect is positive to observe that the content (IPP) is present in thesis and dissertations in all knowledge areas except Linguistics, Literature and Arts (LLA). The content (P) also is present in areas with important potential of patenting as Health Sciences and Engineering.

It's necessary to emphasize that the search was based on the following terms: 'intellectual property' and 'industrial property' according to methodology adopted. Then it's possible that others thesis and dissertations related to patents, copyright, software etc. that did not use these specific terms in title or resume have not been recovered.

\section{Conclusion}

The intensification of discussions about IP in international forums, the implementation of TRIPs and the importance of innovation in a knowledge-intensive economy have made the intellectual property thematic strategic for the development of countries. In Brazil, the new Industrial Property Law (1996) and the establishment of policies and regulations such as the Law of Innovation (2004) created a demand for qualified people to attend issues relating to innovation, technology transfer and commercialization which involves intellectual property.

Based on information contained in the abstracts of thesis and dissertations related about IP retrieved of the Bank of Thesis of Capes it was possible to identify the dynamic of the process of capacity building in IP in Brazil. The results showed that only in the last years started the formation of professionals at the master's and doctorate degree levels being necessary efforts for learning and training in the area.

The research also showed that this capacity building is much concentrated in the Southeast and South regions of Brazil with emphasis on the states of São Paulo and Rio de Janeiro. These two states represent, together, more than $50 \%$ of the total of the national production of thesis and dissertations about IP of the country. It's important to reduce this asymmetry. It's also necessary a better distribution of the formation of competences in diverse knowledge areas. The results indicated that $40 \%$ of the documents analyzed are classified in the subarea law. The qualified formation of people not only related to legal aspects of intellectual property but also in areas related to technology and management is fundamental to promote the technological development of the country.

\section{References}

BUAINAIN, A. M., Carvalho, S.M.P. (2000). Propriedade Intelectual em um Mundo Globalizado. Parcerias Estratégicas, 9, |45-|43.

BRANDELLI, O., Jaguaribe, R. (2007). Propriedade Intelectual: espaços para os países em desenvolvimento. In Villares F., ed. Propriedade Intelectual: tensões entre 0 capital e a sociedade. São Paulo: Ed. Paz e Terra, 270 305. 
CHAVES, G. C., Oliveira, M. A., Hasenclever, L., Melo, L.. M. (2007). A evolução do sistema internacional de propriedade intelectual: proteção patentária para o setor farmacêutico e acesso a medicamentos, Cad. Saúde Pública, 23 (2), 257-267.

BUAINAIN, A.M., Carvalho, S.M.P.; Paulino, S.R.; Yamamura, S. (w.d.). Propriedade Intelectual e Inovação Tecnológica: algumas questões para $\circ$ debate atual..http://www2.desenvolvimento.gov.br/arquivo/sti/pu blicacoes/futAmaDilOportunidades/futIndustria_2_00.pdf (accessed in 05/12/08?

WIPO World Intellectual Property Organization. (2009). What is IP? http://www.wipo.int/about-ip/en/ (accessed in $13 / 01 / 09)$.

INPI Instituto Nacional de Propriedade Industrial. (2009). Acordos Internacionais. http://www.inpi.gov. br/menu-esquerdo/patente/ pasta acordos (accessed in 04/02/09)

GONTIJO, C. (2005). As transformações do sistema de patentes, da Convenção de Paris ao Acordo TRIPS. Fundação Heinrich Böll. http://boell-latinoamerica.org/ download pt/trips 1105.pdf (accessed in 04/02/09) 